\title{
Low Columnar Cell
}

National Cancer Institute

\section{Source}

National Cancer Institute. Low Columnar Cell. NCI Thesaurus. Code C33008.

A simple epithelial cell that is shaped like a short column. 